\title{
Kajian Kritis Keputusan Mahasiswa Studi S-1 Fakultas Ekonomi Reguler Sore Usm
}

\author{
Endang Rusdianti, Sri Purwantini, Paulus Wardoyo \\ endang_rusdianti@yahoo.com, adyalk@gmail.com
}

\begin{abstract}
ABSTRAKSI
Pendidikan tinggi merupakan kelanjutan pendidikan menengah yang diselenggarakan untuk menyiapkan peserta didik menjadi anggota masyarakat yang memiliki kemampuan akademik dan atau profesional yang dapat menerapkan, mengembangkan dan atau menciptakan ilmu pengetahuan teknologi dan atau kesenian. Penelitian ini dirancang sebagai penelitian kualitatif dengan menggunakan pendekatan fenomenalisis dan grounded.sehingga fenomena yang ada bisa digunakan sebagai bahan kajian mengenai faktor-faktor yang memunculkan minat dan kualitas pelayanan serta keputusan memilih program studi. Adapun yang menjadi research partner sebanyak delapan orang mahasiswa aktif kelas reguler sore. Hasil penelitian ini menghasilkan dua proposisi yaitu tentang minat melanjutkan studi di perguruan tinggi dan kualitas pelayanan di perguruan tinggi. Masing-masing proposisi dilengkapi dengan gambar bangunan teori. Yang akhirnya memunculkan model bangunan teori tentang keputusan melanjutkan studi yang merupakan kajian untuk penelitian empirik selanjutnya.
\end{abstract}

Kata kunci : research partner, proposisi, pengujian empirik

\begin{abstract}
Higher education is a continuation of secondary education held to prepare learners to become members of the community who have academic and / or professional skills who can apply, develop and or create science of technology and or art. This research is designed as a qualitative research by using phenomenalisis and grounded approach. So that the phenomenon can be used as a study material on the factors that give rise to the interest and quality of service and the decision to choose the study program. As for the research partner as many as eight students active class regular afternoon. The results of this study resulted in two propositions of interest in continuing studies in universities and service quality in universities. Each proposition comes with a picture of the theory building. Which ultimately led to the theoretical model of the decision to continue the study which is a study for further empirical research.
\end{abstract}

Keywords: research partner, proposition, empirical testing. 


\section{PENDAHULUAN}

Dewasa ini persaingan antar perguruan tinggi dalam menarik mahasiswa baru semakin ketat. Adanya kondisi yang demikian membuat masing-masing perguruan tinggi gencar melakukan berbagai program promosi. untuk menarik mahasiswa baru dengan harapan memperoleh calon mahasiswa yang bermutu tinggi. Dimasa yang akan datang, selain aspek jumlah mahasiswa (kuantitas), aspek mutu mahasiswa (kualitas) juga menjadi salah satu tolok ukur dan pertimbangan penting keberhasilan pengelolaan sebuah perguruan tinggi. Di lain pihak yaitu bagi lulusan sekolah menengah atas sendiri, studi ke jenjang perguruan tinggi dianggap sebagai salah satu cara untuk mewujudkan cita-cita mereka., Kuliah merupakan jaminan dan menjadi dasar bagi kesuksesan mereka di masa depan (Wibowo dan Hardianto, 2012).

Perguruan tinggi merupakan kelanjutan pendidikan menengah yang diselenggarakan untuk menyiapkan peserta didik menjadi masyarakat yang memiliki kemampuan akademik, dan atau profesional yang dapat menerapkan, mengembangkan dan atau menciptakan ilmu pengetahuan teknologi dan atau kesenian (UU RI, No. 2 Tahun 1989). Perguruan tinggi negeri adalah pendidikan tinggi yang diselenggarakan oleh satuan pendidikan dan diadakan oleh pemerintah, dalam hal ini departemen atau lembaga pemerintahan lain, sedangkan perguruan tinggi swasta adalah pendidikan tinggi yang diselenggarakan oleh satuan pendidikan yang diadakan oleh masyarakat. Menurut Undangundang No.2 tahun 1989 (Hardjana, 1994), perbedaan perguruan tinggi negeri dan perguruan tinggi swasta hanya terletak dalam hal siapa yang memiliki dan membiayainya saja, sedang hal lain secara teoritis sama karena dasar kurikulum di perguruan tinggi negeri dan perguruan tinggi swasta sama-sama bersumber pada kurikulum yang berlaku secara nasional yang ditetapkan oleh menteri. Mutu dan efisien perguruan tinggi negeri dan perguruan tinggi swasta juga dinilai oleh badan yang sama yaitu badan akreditasi, dengan kriteria sama tetapi dalam kenyataan karena sejarah, keadaan de fakto dalam hal dosen, fasilitas dan sumber dana pembiayaan serta apresiasi masyarakat perguruan tinggi negeri memberi kesan lebih unggul mutu dan efisiensinya daripada perguruan tinggi swasta. Persaingan yang ketat dalam duniai pendidikan khususnya perguruan tinggi swasta, akan membuat perguruan tinggi swasta sebagai sebuah institusi yang tidak jauh berbeda dengan organisasi bisnis lainnya, yaitu membutuhkan strategi bisnis tertentu untuk dapat bertahan dalam mewujudkan visi dan misinya dan memberikan layanan yang terbaik bagi stakeholder. Tersedianya sumber daya manusia yang menguasai ipteks dan memiliki daya beli yang memadai merupakan hasil dari lembaga pendidikan tinggi yang akan mendorong tumbuhnya lembaga dan industri berbasis ilmu pengetahuan 
Dalam menghadapi era perdagangan bebas kebanyakan lulusan perguruan tinggi menjadi tenaga profesional yang banyak dibutuhkan di dunia industri disamping itu tidak jarang dari lulusannya mampu untuk menciptakan lapangan pekerjaan sendiri. Mahasiswa didefinisikan sebagai orang yang belajar,. terdaftar dan menjalani pendidikan dalam perguruan tinggi (Salim,2002) Badudu dan Zaih (2001) juga mendefinisikan mahasiswa sebagai siswa perguruan tinggi. yang terdiri dari akademik, politeknik, sekolah tinggi, institut dan universitas. Motivasi dalam kegiatan perkuliahan sangat penting karena karena dapat berfungsi sebagai (1) energizer, yakni motor penggerak yang mendorong mahasiswa untuk berbuat sesuatu misalnya perbuatan belajar, (2) directedness, yakni menentukan arah perbuatan ke arah tujuan yang ingin dicapai, (3) patterning, yakni menyelesaikan perbuatan-perbuatan apa yang harus dikerjakan yang serasi guna mencapai tujuan (McClelland, 1997).

Uno (2012) menyatakan harapan untuk berhasil, berisi kesuksesan program, tujuan pengajaran, remedial sosialisasi, penghargaan dari luar yang dapat berisi hadiah, kompetensi yang positif, nilai hasil belajar, Purwanto (2007) menyatakan bahwa kebutuhan atas penghargaan termasuk kebutuhan dihargai karena prestasi, kemampuan, kedudukan atau status dan sebagainya. Sardiman (2011) menyatakan bahwa suatu pekerjaan atau kegiatan belajar itu akan berhasil baik kalau disertai dengan pujian.

Adanya lingkungan yang baik yaitu lingkungan keluarga, lingkungan sekolah dan masyarakat.. Hal ini sejalan dengan pendapat Oemar (2009) menyatakan "inti dari belajar adalah pengalaman dan pengalaman ini diperoleh melalui interaksi dengan lingkungan, baik lingkungan fisik maupun sosial. Sedangkan menurut Slameto (2006) menyatakan lingkungan belajar siswa yang berpengaruh terhadap prestasi belajar terdiri dari lingkungan keluarga, lingkungan sekolah dan lingkungan masyarakat. Dikaitkan dengan kegiatan belajar mengajar, siswa akan berusaha untuk selalu mendekati hal-hal yang menyenangkan (Djaali 2012),.

Berkaitan dengan kemampuan tersebut mahasiswa Perguruan Tinggi Negeri biasanya memiliki kemampuan yang lebih dibandingkan dengan Perguruan Tinggi Swasta, karena untuk masuk ke Perguruan Tinggi Negeri harus melalui seleksi dan persaingan yang sangat ketat, sehingga mahasiswa yang masuk ke perguruan tinggi negeri adalah orang yang benar-benar memiliki kemampuan di atas ratarata. Sebaliknya mahasiswa yang masuk ke PTS kemungkinan besar adalah mahasiswa yang tidak diterima di PTN. Indikator yang dapat dijadikan sebagai prediktor adalah permintaan untuk mengisi lapangan kerja mayoritas adalah mahasiswa yang lulus dari PTN. Selain itu fenomena yang ada menunjukkan bahwa kualitas perguruan tinggi negeri memang lebih unggul dibandingkan perguruan tinggi swasta. Seperti dikemukakan oleh Eko (2004) berdasarkan indeks prestasi dan waktu kelulusan mahasiswa dari seluruh perguruan tinggi di Indonesia tidak ada satupun perguruan tinggi swasta yang masuk sepuluh besar. Akibatnya, 50\% lebih mahasiswa PTS 
hanya berlomba untuk menyelesaikan pendidikannya, tanpa memperhatikan kualitas. Di samping input yang buruk, tim evaluasi juga menemukan, kelulusan mahasiswa (out put) umumnya lolos dari persyaratan. Artinya, masih banyak mahasiswa yang diwajibkan lulus maksimal 14 semester untuk program S1, tapi tidak dapat memenuhi peraturan itu.

Kualitas pendidikan perguruan tinggi di Indonesia beragam sekali penyebabnya, misalnya: jumlah dan kualifikasi staf pengajar, kuantitas staf administrasi yang memadai, fasilitas penunjang (lab, perpustakaan, IT) dan atmosfir akademik yang kondusif.Undangundang Sistem Pendidikan Nasional (Sisdiknas) Nomor 20 Tahun 2003 pasal 19 (1) menyatakan, pendidikan tinggi Indonesia mencakup pendidikan diploma, sarjana, magister, spesialis, dan doctor dan dalam pasal 20(3), menyatakan bahwa perguruan tinggi dapat menyelenggarakan program akademik, profesi, dan/atau vokasi.

Buruknya kualitas mahasiswa bukan hanya dalam kemampuan akademis yaitu berpikir secara kritis dan analitis dalam satu masalah tetapi juga kemauan untuk belajar dengan cara yang benar artinya seorang mahasiswa yang sedang kuliah bukan hanya mengejar nilai/IPK yang tinggi dalam satu mata kuliah atau terpenuhi jumlah SKS sehingga bisa meraih gelar sarjana-S1 dalam waktu singkat. Namun mahasiswa sadar betul bahwa ia mengambil jurusan dan matakuliah yang memang ingin dikuasai secara mendalam sehingga hasil yang dicapai bukan hanya nilai tinggi tetapi dapat diterapkan dalam dunia kerja kelak.
Kenyataan lainnya adalah kebanyakan mahasiswa sekarang cenderung menyukai halhal yang bersifat instant. Mereka jarang mau kerja lembur baik itu di laboratorium maupun di perpustakaan. Keberhasilan mahasiswa dalam belajar dipengaruhi oleh faktor-faktor psikologis maupun sosial. Bagi mahasiswa pendatang yang merantau ke daerah lain tempat kos akan menjadi kehidupan baru bagi mereka. Banyaknya mahasiswa pendatang yang tinggal untuk menetap dengan berbagai tujuan tersebut menghasilkan percampuran kebudayaan dengan masyarakat setempat. Pergaulan antara pendatang yang berasal dari berbagai latar belakang budaya yang berbeda-beda dengan masyarakat setempat memberikan nuansa khas tersendiri. Hal pertama yang dijumpai mahasiswa pendatang adalah lingkungan sosial baru, bertemu dan bergaul dengan orang yang belum dikenalnya dengan latar belakang yang berbeda serta watak dan kebiasaan yang berbeda pula dan mungkin berbeda jauh dengan lingkungan yang pernah dijumpai ketika masih tinggal dengan orang tuanya, misalnya teman baru, kebudayaan yang berbeda, status sosial ekonomi yang berbeda dan lain-lain. Asimilasi dan akulturasi budaya itu lama kelamaan akan terbentuk seiring berjalannya waktu. Tidak jarang dalam pergaulan tersebut sering muncul gesekan-gesekan akibat ketidaksesuaian budaya antara pendatang dan masyarakat setempat sehingga mengakibatkan berbagai konflik Berpijak dari kenyataan tersebut, yang harus dilakukan oleh semua mahasiswa baik itu di perguruan tinggi negeri maupun swasta, pendatang dan bukan pendatang pada dasarnya adalah menumbuhkan inisiatif dan daya kreatif

Jurnal Dinamika Sosial Budaya, Volume 19, Nomor 1, Juni 2017 
sendiri untuk meraih prestasi tertinggi (need for achievement).

Prestise adalah kebanggaan yang mewakili jiwa muda kita sebagai mahasiswa. Keinginan untuk bergaul dengan sesama dan mencari kawan sebanyak-banyaknya adalah beberapa di antara banyak motivasi yang terkadang hadir di dalam benak kita. Termasuk di antaranya kebanggaan bisa masuk ke universitas/jurusan favorit. Siswa seperti mereka memiliki empat jenis patokan dalam memilih targetnya; Pertama, patokan perguruan tinggi. Jurusan apa saja terserah Kedua, patokan jurusan. Universitas mana saja terserah, Ketiga, patokan kota. Universitas mana saja, jurusan apa saja Keempat, patokan prospek. Di mana saja boleh, asal kedinasan dengan prospek jelas. Kita pasti bangga ketika diterima di perguruan tinggi yang kita inginkan, dengan patokan seperti yang saya uraikan di atas.

Profesi adalah orientasi hasil dari proses selama kita kuliah.Karena logika mereka adalah 'karir menjanjikan kesejahteraan hidup, dan kesejahteraan hidup menjanjikan kebahagiaan'.Ketika para calon mahasiswa melakukan survey jurusan, biasanya mereka akan menanyakan prospek kerja dari jurusan yang mereka inginkan. Bahkan tak jarang yang sampai bertanya gaji dan hal-hal lain yang menunjang kesejahteraan hidup mereka ke depan.Mayoritas calon mahasiswa memiliki paradigma bahwa karir adalah hal penting. Karena karir menentukan status sosial mereka di masyarakat. Sehingga mereka terdorong untuk mencari sebesar-besar peluang, agar nanti setelah kuliah dengan mudah mendapatkan pekerjaan. Keinginan seorang calon mahasiswa untuk masuk ke jurusan dengan prospek kerja jelas. Ketika orientasi seorang calon mahasiswa adalah profesi maka tujuannya setingkat lebih tinggi daripada sekedar masuk ke jurusan dengan prospek kerja baik. Mahasiswa yang ingin berkontribusi tidak terlalu memikirkan hal-hal teknis yang akan dibebankan padanya dalam hal ini berupa pilihan jurusan-. Mahasiswa seperti ini memahami, bahwa kuliah hanyalah secuil usaha dari banyak jalan yang bisa ditempuh untuk menuju kematangan. dalam diri seseorang yang ditandai dengan munculnya "feeling" dan didahului dengan tanggapan terhadap adanya tujuan (Sardiman, 2010).

Setiap mahasiswa memiliki dorongan yang kuat dalam penentuan pemilihan program studi yang akan mereka jalani, dapat di katakan bahwa semangat mahasiswa dalam memilih suatu program studi ditentukan oleh motivasi internal adalah motivasi yang tumbuh dari dalam diri sendiri, atau dapat dikatakan sebagai keinginan kuat yang timbul dari dalam diri. Motivasi eksternal adalah motivasi yang tumbuh disebabkan oleh faktor-faktor dari luar seperti faktor lingkungan, faktor keluarga, dan faktor masyarakat. Penelitian Jamaluddin Sawaji, Djabir Hamzah, dan Idrus Taba (2010) menyatakan bahwa biaya pendidikan sangat berkaitan erat dengan kualitas pelayanan sehingga mempengaruhi citra dari perguruan tinggi.

Hasil penelitian Wibowo et al. (2012) menyebutkan bahwa ada berbagai subjek yang bisa berperan sebagai pendorong sekaligus juga penghambat intensi lulusan sekolah menengah di Indonesia untuk studi ke perguruan tinggi, yaitu 
diri siswa sendiri, keluarga, guru, teman, dan pihak perguruan tinggi. Selain itu, kualitas layanan merupakan salah satu faktor kriteria penting kampus favorit. Kualitas layanan ini bisa berupa kualitas dosen, fasilitas fisik, mata kuliah, dan lingkungan kampus. Di samping faktor kualitas layanan, beberapa kriteria perguruan tinggi favorit lain adalah prestasi lulusan/alumni, hubungan eksternal, nilai-nilai (values), reputasi, prospek kerja, mutu dan jumlah mahasiswa, biaya studi, dan manajemen perguruan tinggi. Minat merupakan suatu keinginan yang cenderung menetap pada diri seseorang untuk mengarahkan pada suatu pilihan tertentu sebagai kebutuhannya, kemudian dilanjutkan untuk diwujudkan dalam tindakan yang nyata dengan adanya perhatian pada objek yang diinginkannya itu untuk mencari informasi sebagai wawasan bagi dirinya. Minat pada diri seseorang tidak terbentuk secara tiba-tiba, tetapi terbentuk melalui proses yang dilakukannya. Ini berarti bahwa minat pada diri seseorang tidak hanya terbentuk dari dirinya akan tetapi ada pengaruh juga dari luar dirinya, termasuk lingkungan (Suprapto, 2007).

Universitas Semarang yang lebih dikenal dengan USM, merupakan salah satu perguruan tinggi swasta yg besar di Kota Semarang.Dengan jumlah mahasiswa yang terus bertambah tentu membutuhkan pengelolaan yang cerdas agar mutu dan kualitas lulusan dapat bersaing di pasar tenaga kerja. USM memiliki 6 fakultas untuk jenjang S-1 dan Program Pasca Sarjana.Berikut ini data jumlah penerimaan mahasiswa fakultas ekonomi regular sore tahun 2013 sd 2015:

Jurnal Dinamika Sosial Budaya, Volume 19, Nomor 1, Juni 2017
Dari data, terlihat adanya peningkatan jumlah mahasiswa yang semakin menyolok dari tahun ke tahun, Tahun 2014 mengalami peningkatan sebesar 22,1\% dan tahun 2015 mengalami peningkatan 23,1\%. Masalah dalam penelitian ini adalah fenomena semakin meningkatnya jumlah mahasiswa fakultas ekonomi kelas reguler sore USM dibandingkan dengan jumlah mahasiswa kelas reguler sore fakultas lain di lingkungan USM terutama di program studi S1. dapat dijadikan sebagai model atas faktor-faktor penentu keputusan melanjutkan studi S1 reguler sore di USM. Sehingga bisa memunculkan proposisi tentang minat melanjutkan studi dan proposisi tentang faktor pelayanan yang membentuk model tentang keputusan melanjutkan studi

\section{TELAAH PUSTAKA}

\section{Dasar Penyelenggaraan Pendidikan Tinggi}

Undang-Undang Republik Indonesia Nomor 20 Tahun2003 Tentang Sistem Pendidikan Nasional dalam pasal 19 ayat 1 disebutkan bahwa pendidikan tinggi merupakan jenjang pendidikan menengah yang mencakup program pendidikan diploma, sarjana, spesialis, dan doktor yang diselenggarakan oleh pendidikan tinggi.

\section{Pemasaran Jasa Pendidikan Perguruan Tinggi}

Pemasaran dalam lembaga pendidikan, menurut Hidayat dan Machali (2012) dapat dimaknai sebagai sebuah lembaga yang bergerak dibidang layanan jasa pendidikan yang 
kegiatannya melayani konsumen berupa siswa, mahasiswa, orang tua siswa dan masyarakat umum sebagai stakeholder- nya. Analisis proses pengambilan keputusan mahasiswa dalam memilih program studi telah diteliti Mashur Razak (2008) hasilnya (1) Sosial budaya berpengaruh positif dan signifikan terhadap faktor pribadi, motivasi dan pengambilan keputusan, namun tidak signifikan terhadap formasi sikap dan persepsi mahasiswa (2) Kelompok rujukan berpengaruh positif dan signifikan terhadap faktor pribadi, motivasi, persepsi, formasi sikap dan pengambilan keputusan. (3) Faktor pribadi berpengaruh positif dan signifikan terhadap motivasi, persepsi, formasi sikap, namun tidak signifikan terhadap pengambilan keputusan (4) Motivasi berpengaruh positif dan signifikan terhadap persepsi, formasi sikap dan pengambilan keputusan (5) Persepsi berpengaruh positif terhadap pengambilan keputusan, namun tidak signifikan terhadap formasi sikap dan persepsi. Padlee, et al(2010), menghasilkan faktor utama adalah fokus pelanggan dan fasilitas yang digunakan mahasiswa. Yoseph Kee Ming Sia (2011), hasilnya biaya, lokasi, rekan, sekolah asal dan kunjungan kampus. Andriani Kusumawati (2010) hasilnya biaya, reputasi PT, prospek lapangan pekerjaan, keputusan orang tua dan kualitas.

\section{Minat Melanjutkan Studi}

Minat melanjutkan studi adalah sikap seseorang yang membuat dirinya merasa senang, tertarik dan mencurahkan perhatiannya sehingga mempunyai keinginan yang kuat untuk mencari dan terlibat secara langsung studi di perguruan tinggi. Djaali (2008) menyatakan bahwa minat pada dasarnya merupakan penerimaan akan sesuatu hubungan antara diri sendiri dengan sesuatu di luar diri

\section{Biaya Pendidikan}

Prof Dr Dedi S (2007), biaya pendidikan merupakan komponen instrumental untuk bisa mendukung proses pendidikan, terkait dengan jumlah biaya yang akan dikeluarkan oleh mahasiswa.Biaya pendidikan merupakan keseluruhan pengorbanan finansial yang harus ditanggung mahasiswa dalam masa studinya.

\section{Lokasi}

Lokasi merupakan tempat yang dipilih untuk melakukan kegiatan dalam proses pembelajaran

\section{Gethok Tular (Worth of Mouth)}

Merupakan komunikasi personal berupa ucapan yang berasal dari mulut ke mulut.

\section{Status Sosial}

Merupakan kedudukan seseorang dalam kelompok masyarakat karena keterlibatnnya.

\section{METODE PENELITIAN}

\section{Disain/rancangan penelitian}

Disain penelitian ini adalah berupa penelitian kualitatif dengan menggunakan pendekatan fenomenologi permasalahan yang diangkat merupakan permasalahan yang tidak bisa dijelaskan dan dianalisa melalui data-data statistik sehingga perlu pendekatan tertentu untuk memahaminya. Heru Basuki (2006) penelitian kualitatif adalah penelitian yang bertujuan untuk mendapatkan pemahaman yang mendalam tentang masalah manusia dan sosial, peneliti menginterpretasikan bagaimana subjek memperoleh makna dari lingkungan sekeliling dan bagaimana makna tersebut mempengaruhi perilaku mereka. 


\section{Teknik Pengumpulan Data}

Pada penelitian ini digunakan metode wawancara dengan pedoman umum, yang mencantumkan isu-isu yang harus diliput tanpa menentukan urutan pertanyaan, bahkan mungkin tanpa bentuk pertanyaan eksplisit. Teknik observasi nonpartisipan, dimana peneliti tidak ikut serta dalam kegiatan yang dilakukan subjek. Peneliti berfungsi sebagai penonton dan pencatat langsung dimana pencatat hasil observasi segera setelah pengamatan dilakukan atau ketika pengamatan sedang berlangsung.

\section{Teknik Analisis Data}

Adapun proses analisis data yang dilakukan dengan teknik data kualitatif oleh Marshall dan Rossman. (1995) dengan beberapa tahapan, yaitu :

1. Mengorganisasikan Data didapatkan langsung dari subjek melalui wawancara, direkam dengan tape recorder dibantu alat tulis lainnya. Kemudian dibuatkan transkripnya dengan mengubah hasil wawancara dari bentuk rekaman menjadi bentuk tertulis secara verbatim setelah selesai menemui subjek. Data yang telah didapat dibaca berulang ulang, agar dingerti benar data atau hasil yang telah didapat.

2. Pengelompokan Berdasarkan Kategori, Transkrip wawancara dibuat koding, dipilih data yang relevan dengan pokok pembicaraan. Data yang relevan diberi tema, kemudian dikategorikan.

3. Menguji Asumsi atau Permasalahan yang Ada Terhadap Data Setelah kategori dan pola data tergambar dengan jelas kemudian diuji terhadap asumsi yang dikembangkan dalam penelitian ini. Pada tahap ini kategori yang telah didapat melalui analisis ditinjau kembali berdasarkan landasan teori, Sehingga dapat dicocokkan apakah ada kesamaan antara landasan teoritis dengan hasil yang dicapai. Walaupun penelitian ini tidak memiliki hipotesis tertentu, namun dari landasan teori dapat dibuat asumsi asumsi mengenai hubungan antara konsep-konsep dan faktor-faktor yang ada.

4. Mencari Alternatif Penjelasan Bagi Data. Berdasarkan pada kesimpulan yang telah didapat dari kaitan tersebut dicari alternatif penjelasan tentang kesimpulan yang telah didapat. Sebab dalam penelitian kualitatif memang selalu ada alternatif penjelasan yang lain melalui referensi atau teori-teori. Alternatif ini akan sangat berguna pada bagian kesimpulan, diskusi dan saran.

5. Menulis Hasil Penelitian Analisis data subjek dan significant other yang telah berhasil dikumpulkan, merupakan suatu hal yang membantu untuk memeriksa kembali apakah kesimpulan yang dibuat telah selesai. Dalam penelitian ini, penulisan yang dipakai adalah presentasi data yang didapat yaitu, penulisan datadata hasil penelitian berdasarkan wawancara mendalam dan observasi dengan subjek. Prosesnya dimulai dari data-data yang telah diperoleh dari tiap subjek dibaca berulang kali sampai penulis mengerti benar permasalahannya lalu dianalisis, sehingga didapatkan gambaran mengenai penghayatan pengalaman masingmasing subjek. Selanjutnya dilakukan interpretasi secara keseluruhan dimana didalamnya mencakup keseluruhan kesimpulan dari hasil penelitian

\section{Populasi dan Sampel}

Sumber data adalah 8 mahasiswa. Karena ini merupakan penelitian kualitatif, maka dalam 
melaksanakan proses penelitian akan digunakan research partner/informan yang akan dijadikan sebagai nara sumber.

\section{PEMBAHASAN}

\section{Hasil Wawancara dengan Research Partner}

Ada delapan pertanyaan penelitian. Dengan mempertimbangkan mereka berkeberatan namanya diungkap maka nama dari research partner diberi inisal. Nama selengkapnya ada pada peneliti. Adapun jawaban dari research partner sebagai berikut :

\section{Melanjutkan studi}

Pertanyaan pertama " Mengapa Sdr berkeinginan melanjutkan studi? " Hasil jawaban dari research partner dapat dikelompokkan ke dalam kategori yaitu a) ingin mendapatkan ilmu yang dapat digunakan untuk mendukung karier di tempat bekerja yang sekarang atau sebagai modal untuk mengadu nasib untuk mencari pekerjaan yang lebih baik, b) untuk menambah pengetahuan dalam mengelola bisnis yang telah dilakukan selama ini, c) untuk memperbaiki status sosial di masyarakat IDP, yang bersangkutan saat ini telah bekerja di perusahaan swasta, karena pendidikan yang bersangkutan hanya Sekolah Lanjutan Tingkat Atas, maka pekerjaan yang diterima sebatas latar belakang pendidikan formal.dan kemampuan yang dimiliki. DL, melanjutkan studi dengan tujuan mendapatkan pengetahuan yang bisa diaplikasikan dalam pekerjaan, sehingga usaha yang telah dirintis selama ini bisa lebih berkembang. MTR , memiliki motivasi studi untuk bisa mengembangkan relasi usaha. Afa, melanjutkan studi untuk memperbaki status sosial, sehingga bisa lebih dipandang sebagai orang yang memiliki pendidikan tinggi.

\section{Memilih Fakultas}

Pertanyaan kedua “ Mengapa memilih Fakultas Ekonomi di Universitas Semarang? Ada tiga kategori jawaban yaitu rekomendasi teman, proses belajar mengajar yang tertib dan biaya kuliah. IDP, mengikuti rekomendasi temannya yang terlebih dahulu telah kuliah di Fakultas Ekonomi. DL perkuliahan dilaksanakan secara fleksibel, yaitu regular sore hari atau kelas karyawan/akhir pekan, sehingga calon mahasiswa bisa memilih waktu kuliah yang sesuai. Proses belajar mengajar yang terstruktur dan lebih baik juga menjadi pertimbangan calon mahasiswa memilih studi di FES USM seperti yang disampaikan salah satu research partner yang bernama Iqm. AST, pertimbangan biaya, dimana biaya kuliah untuk kelas reguler sore atau kelas karyawan cukup terjangkau dan bisa dibayar dengan model angsuran per bulan, sehingga ini menjadi salah satu daya tarik, khususnya bagi mereka yang memiliki keterbatasan pendapatan.

\section{Proses belajar mengajar}

Pertanyaan ketiga", bagaiaman kesan saudara terhadap para dosen yang mengajar ? Secara keseluruhan ada tiga kategori yaitu : a) disiplin, b) komunikatif, c) kami tidak menyukai model kuliah dengan cara presentasi individual/atau diskusi kelompok. IDP, berdasarkan pengalaman selama kuliah, melihat para dosen senior di FE USM sangat disiplin sekali dalam mengajar dan memiliki sikap yang tegas dan berwibawa, hal ini juga diperkuat oleh pendapat DL, para dosen dalam memberikan kuliah sangat komunikatif, sehingga materi yang diajarkan 
menjadi lebih mudah dipahami. Iqm, jika yang mengajar para asisten dosen, sangat berkebalikan, terkesan masih kurang pengalaman, dan tidak menguasai materi yang diajarkan. PKP, kuliah di FE USM itu sarat dengan berbagai tugas-tugas mandiri atau kelompok, dan ini sangat membedakan dengan kuliah di tempat yang lain. Karena latar belakang dan kepandaian dari mahasiswa sangat heterogen, AST, menyampaikan sejatinya para mahasiswa tidak menyukai kuliah dengan model presentasi dan diskusi kelompok, hal ini dikarenakan mereka pada umumnya sudah lelah dengan tugas pekerjaan di kantor, selain itu apa yang disampaikan rekan-rekan mahasiswa dalam presentasi ataupun dalam diskusi kelompok kurang bisa diterima, Mereka lebih suka pada konsep TCL daripada SCL

Pertanyaan ke empat "bagaimana kesan Sdr terhadap proses belajar mengajar dikelas", empat kateori jawaban :a) cara mengajarnya efisien dan efektif, b) penilaian harus lebih fair, c) diperlukan adanya handout/modul, d) asisten dosen kompetensinya masih sangat kurang.: para dosen senior kalau mengajar kebanyakan on time dan menggunakan waktu secara efisien, sehingga mata kuliah yang diajarkan bisa sesuai dengan kontrak kuliah yang disepakati di awal (IDP). DL, menyebutkan bahwa dalam memberikan nilai hasil ujian, masih kurang mencerminkan kondisi yang sesungguhnya dari mahasiswa. Karena proses ujian pengawasannya kurang ketat, sehingga dimungkinkan masih ada celah bagi para mahasiswa untuk saling contek. PKP, sebaiknya ujian akhir semester tidak dilakukan dengan cara take home, karena ini sangat merugikan mahasiswa yang aktif dan benar benar belajar. Iqm, menyarankan sebaiknya untuk setiap mata kuliah dilengkapi dengan handout atau modul, sehingga akan sangat membantu para mahasiswa dalam memahmi mata kuliah yang diberikan oleh para dosen. Sementara itu, sebaiknya asisten yang dipergunakan adalah asisten yang memiliki kompetensi tidak jauh dari para dosen senior, sehingga ini akan lebih menarik dan membuat kami lebih bersemangat lagi dalam mengikuti perkuliahan

\section{Sarana \& Prasarana}

Pertanyaan kelima berbunyi “, apakah prasarana yang terdapat di fakultas ekonomi sudah memadai ? jawabannya dikelompokkan menjadi tiga kategori yaitu : a) daya tampung kelas, b) kebersihan lingkungan, c) area parker DL, ruang kuliah di FE cukup nyaman, karena dilengkapi dengan system pendingin udara yang bagus. Iqm, ruang kuliah di lantai 1 dan 2 adalah ruang yang kecil/sempit dan sering diisi dengan jumlah peserta/mahasiswa yang melebih kapasitas yang seharusnya, sehingga ini membuat suasana kuliah menjadi tidak nyaman dan cenderung gaduh.Afa, area parkir yang ada sangat sempit, sehingga harus berebut, apalagi jika Kampus mengadakan kegiatan UKM musik, badminton dsb, yang merebut banyak lahan parkir. Selain itu, jika mahasiswa membawa mobil, maka kami harus berebut dengan mahasiswa S2. PKP, kebersihan toilet dirasa masih kurang mendapat perhatian, airnya sering mati. MTR nmenambahkan bahwa toilet wanita tidak dilengkapi dengan cermin.

Pertanyaan ke enam lebih banyak berhubungan dengan sarana perkuliahan di USM. Adapun pertanyaannya berbunyi sebagai berikut : “Apa pendapat Saudara dengan sarana perkuliahaan yang ada saat ini? jawaban dikelompokkan dalam tiga kategori yaitu : a) 
Perawaran sarana perkuliahan, b) jumlah buku perpustakaan yang kurang memdadai, 3) fasilitas pendukung yang masih kurang. IDP, sistem audio yang tersedia ruang kuliah saat ini kurang mendukung, DL, sarana perpustkaan sudah cukup memadai, namun dari sisi jumlah buku untuk setiap judul masih kurang, sehingga kalau pinjam sering harus berebut. Iqm, perlunya dilengkapi dengan jam dinding serta kalender.

Afa, LCD di beberapa ruang kuliah tidak bisa menampilkan gambar yang cerah, sehingga sangat mengganggu pengelihatan, selain itu karena ruang yang sempit dan jumlah peserta kuliah banyak, maka membuat dosen duduknya agak mundur dan tidak bisa membaca apa yan ng ditampilkan di dalam layar, dan ini akan sangat mengganggu saat dosen tersebut menjelaskan tentang pokok bahasan, apalagi kalau harus memberi penjelasan di papan tulis. MTR, kurang disiplinnya mahasiswa dalam membuang sampah, sehingga menimbulkan kesan jorok. PKP, bahwa failitas hot spot saat ini sudah cukup memadai dan sangat mudah untuk diakses dari berbagai tempat.

\section{Pelayanan Tata Usaha}

Pertanyaan kedelapan, yang merupakan pertanyaan terakhir berbunyi sebagai berikut : "bagaimana pendapat saudara dengan pelayanan yang diberikan oleh bagian tata usaha fakultas ekonomi selama ini ? Jawaban dikelompokkan dalam satu kelompok yaitu : empati. IDP, petugas tata usaha FE USM dalam melayani mahasiswa cukup ramah dan sopan. Iqm, menjawab jika memerlukan informasi saya sering mencari atau berusaha membaca di papan pengumuman, tetapi informasi yang ditempel sudah basi dan tidak di-up date, MTR, menemukan petugas tata usaha yang melayaninya belum sepenuh hati, disertai nada bicaranya kurang enak . AST, jika petugas ditanya tentang barang yang tertinggal di kelas, jawaban yang diberikan oleh petugas kurang simpatik.

\section{Kaitan Konsep dengan pembentukan Proposisi}

\section{a. Kaitan konsep Lokasi, Biaya, WOM,}

\section{Status Sosial, Minat dengan Keputusan Melanjutkan Studi}

Suhartono (2009) menjelaskan bahwa pendidikan adalah kegiatan pembelajaran yang berlangsung sepanjang jaman dalam segala situasi kehidupan. Sedangkan UU No 22 tahun 2003 pasal 3 yang menyatakan bahwa: Pendidikan nasional berfungsi mengembangkan kemampuan dan membentuk watak serta peradaban bangsa yang bermartabat dalam rangka mencerdaskan kehidupan bangsa, bertujuan untuk berkembangnya potensi peserta didik agar menjadi manusia yang beriman dan bertaqwa pada Tuhan Yang Maha Esa, beraklaq mulia, sehat berilmu, cakap, kreatif, mandiri dan menjadi warga yang demokratis dan bertanggungjawab. . Dalam literatur ilmu ekonomi, secara jelas menunjukkan bahwa harga merupakan salah satu faktor yang penting yang harus dipertimbangkan dalam mengembangkan strategi. Dalam banyak kasus, harga merupakan variabel keputusan yang paling penting yang diambil oleh pelanggan karena berbagai alasan. Harga merupakan sejumlah uang atau barang atau jasa yang ditukar pembeli untuk beraneka produk atau jasa yang disediakan penjual. Sedangkan Steven dan Wiesberg (2007) menyatakan harga merupakan pengorbanan ekonomis yang dilakukan pelanggan untuk memperoleh produk atau jasa. Selain itu harga adalah suatu faktor penting bagi pelanggan dalam mengambil keputusan untuk melakukan transaksi atau tidak. Sehingga dapat disimpulkan bahwa 
harga adalah sejumlah uang yang telah ditentukan perusahaan sebagai imbalan barang atau jasa yang diperdagangkan dan sesuatu yang lain yang diadakan perusahaan untuk memuaskan keinginan pelanggan serta merupakan salah satu faktor penting dalam pengambilan

Menurut Swastha (2002), lokasi adalah tempat dimana suatu usaha atau aktivitas usaha d ilakukan. Faktor penting dalam pengembangan suatu usaha adalah letak lokasi terhadap daerah perkotaan, cara pencapaian dan waktu tempuh lokasi tujuan. Faktor lokasi yang baik adalah relatifuntuk setiap jenis usaha yang berbeda. Sedangkan menurut Lupiyoadi dan Hamdani (2011:92), lokasi adalah keputusan yang dibuat perusahaan atau instansi pendidikan berkaitan dengan di mana operasi dan stafnya akan ditempatkan. Berdasarkan pendapat tersebut di atas, maka dapat disimpulkan bahwa yang dimaksud lokasi adalah suatu keputusan yang dibuat perusahaan atau instansi pendidikan untuk menentukan tempat usaha, aktivitas usaha atau kegiatan operasional. Pentingnya lokasi bagi instansi pendidikan tergantung dari jenis dan derajat interaksi yang terlibat. Menurut Fandy Tjiptono (2002:41-42), indikator-indikator dalam penentuan lokasi adalah sebagai berikut: Akses lokasi Keberadaan atau letak perguruan tinggi terhadap objek penting seperti pusatperbelanjaan, toko buku, dan fasilitas penunjang lainnya cukup dekat, sehingga akan memudahkan mahasiswa dalam mengakses kebutuhannya. Tempat parkir yang luas dan aman Kemudahan dalam menempatkan atau memarkir kendaraan tanpa harus ada rasa takut dan was-was akan mendapat gangguan atau kejahatan dari orang lain. Lingkungan yang mendukung Kenyamanan di tempat sekitar untuk dijadikan wadah sosilisasi dan dapat menjadi komunitas pergaulan yang kondusif. Kemudahan akses menuju perusahaan atau perguruan tinggi, letak yang tidak begitu jauh dan kemudahan akses menuju objek penting dapat meningkatkan minat konsumen untuk mendatangi perusahaan atau perguruan tinggi tersebut untuk melakukan pembelian, karena dengan kemudahan tersebut konsumen tidak harus mengeluarkan biaya tambahan atau harus khawatir dengan lingkungan dariperguruan tinggi tersebut.

$$
\text { Status merupakan kedudukan }
$$
seseorang yang dapat ditinjau terlepas dari individunya. Jadi status merupakan kedudukan obyektif yang member hak dan kewajiban kepada orang yang menempati kedudukan tadi. Kedudukan (status) sering kali dibedakan dengan kedudukan sosial (social status). Kedudukan adalah sebagai tempat atau posisi seseorangdalam suatu kelompok sosial, sehubungan dengan orang lain dalam kelompok tersebut, atau tempat suatu kelompok sehubungan dengan kelompok-kelompok lain di dalam kelompok yang lebih besar lagi. Sedangkan kedudukan sosial adalah tempat seseorang secara umum dalam masyarakat sehubungan dengan orang lain, dalam arti kewajibannya. Dengan demikian kedudukan sosial tidaklah semata mata merupakan kumpulan kedudukan-kedudukan seseorang dalam kelompok yang berbeda, tapi kedudukan sosial tersebut mempengaruhi kedudukan orang tad idalam kelompok sosial yang berbeda. Adapun status dalam stratifikasi sosial adalah tempat atau posisi seseorang dalam suatu kelompok sosial dalam masyarakat, sehubungan dengan orang-orang lain dalam kelompok 
tersebut atau masyarakat. Setiap masyarakat pasti mempunyai atau memiliki sesuatu yang dihargainya. Sesuatu yang dihargai inilah sesengguhnya merupakan embrio atau bibit yang dapat menumbuhkan adanya sistem berlapis lapis, di dalam masyarakat itu. Biasanya barang dihargai itu mungkin berupa uang, benda-benda yang punya sifat ekonomi, tanah, kekuasaan, ilmu pengetahuan, sesolehan dalam agama atau juga keturunan dari keluarga yang terhormat. Biasanya diantara banyak status yang dimiliki sesorang, salah satu statusnya yang tertinggi (atau dianggap tertinggi oleh masyarakat) merupakan cirri identitas sosialnya yang terpokok. Pekerjaan seseorang, biasanya dianggap sebagai status tetap dan tertinggi, walaupun tidak senantiasa demikian halnya. Hal ini antara lain disebabkan karena penghasilan pekerjaan tertentu juga dapat menentukan tinggi rendahnya status seseorang. Jenis-Jenis status sosial : 1. Ascribed Status adalah tipe status yang didapat sejak lahir seperti jenis kelamin, ras, kasta, golongan, keturunan, suku, usia, dan lain sebagainya. 2. Achieved Status adalah status sosial yang didapat sesorang karena kerja keras dan usaha yang dilakukannya. Contoh achieved status yaitu seperti harta kekayaan, tingkat pendidikan, pekerjaan, dll. Ada dua sifat dari sistem pelapisan dalam masyarakat, yaitu bersifat tertutup (closed social stratification), dan bersifat terbuka (opened sosial stratification). Sistem pelapisan masyarakat yang bersifat tertutup membatasi kemungkinan berpindahnya seseorang dari lapisan satu ke lapisan yang lain, baik ke lapisan atas ataupun ke lapisan yang lebih rendah Dalam sistem tertutup seperti ini stausatunya cara untuk

Jurnal Dinamika Sosial Budaya, Volume 19, Nomor 1, Juni 2017 menjadi anggota suatu lapisan tertentu dalam masyarakat adalah karena kelahiran, seperti kasta. Sedangkan dalam sistem terbuka, setiap anggota setiap anggota masyarakat mempunyai kesempatan untuk berusaha dengan kemampuannya sendiri. Apabila mampu dan beruntung seseorang dapat untuk naik ke lapisan yang lebih atas, atau bagi mereka yang tidak beruntung dapatv turun ke lapisan yang lebih rendah.

\section{Getok Tular (WOM)}

Minat beli merupakan kecenderungan konsumen untuk membeli suatu merek atau mengambil tindakan yang berhubungan dengan pembelian yang diukur dengan tingkat kemungkinan konsumen melakukan pembelian (Assael, 2001). Mehta (1994: 66) mendefinisikan minat beli sebagai kecenderungan konsumen untuk membeli suatu merek atau mengambil tindakan yang berhubungan dengan pembelian yang diukur dengan tingkat kemungkinan konsumen melakukan pembelian. Pengertian minat beli menurut Howard (1994) ( Durianto dan Liana, 2004: 44) adalah minat beli merupakan sesuatu yang berhubungan dengan rencana konsumen untuk membeli produk tertentu serta berapa banyak unit produk yang dibutuhkan pada periode tertentu. Dari apa yang diuraikan tersebut dapat dikatakan bahwa minat beli sesungguhnya merupakan pernyataan mental konsumen yan direfleksikan dengan rencan untukt membeli sesuatu hal, jika hal ini dikaitkan dengan pendidikan tinggi, maka minat membeli adalah sebuah pernyataan mental konsumen yang merefleksikan dirinya untuk melanjutkan studi pada suatu program studi di perguruan tinggi. Oleh 
karena itu proposisi yang disajikan berbunyi sebagai berikut :

Minat melanjutkan studi di perguruan tinggi sangat ditentukan oleh biaya pendidikan, lokasi, referensi pengalaman orang lain serta status social yang berlaku di masyakarat, sehingga semakin tinggi minat yang dimiliki, semakin tinggi pula keputusan untuk melanjutkan studi di perguruan tinggi.

Secara piktographis dapat disajikan sebagai berikut :

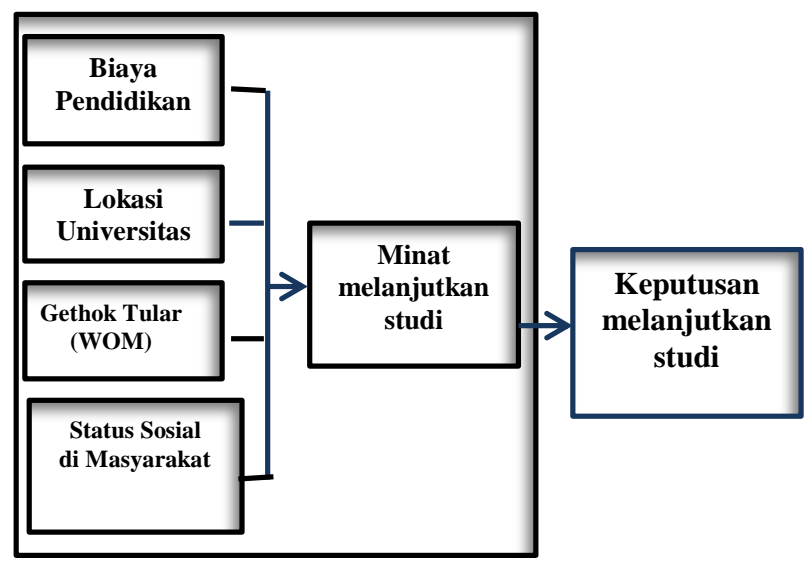

Gambar 4.1. Gambar Minat Melanjutkan Studi

\section{b. Kaitan Konsep Komunikasi Interpersonal, empati dan pelayanan}

Konsep komunikasi interpersonal adalah penyampaian pesan oleh satu orang dan penerimaan pesan oleh orang lain atau sekelompok kecil orang, dengan berbagai dampaknya dan dengan peluang untuk memberikan umpan balik segera Dari pengertian tersebut dapt disimpulkan bahwa dalam komunikasi interpersonal minimal akan diteemui adanya dua pihak yaitu pihak mengajak bicara dan pihak yang diajak bicara. Dalam komunikasi ini berati akan melibatkan kemampuan bertanya dan kemampuan mendengar. Kemampuan bertanya bisa diartikan sebagai kemampuan untuk menanyakan tentang sesuatu hal dan kemampuan bendengar adalah kemampuan untuk menangkap pesan atau penjelasan dari pihak lawan bicara. Agar komunikasi bisa berjalan lancar, maka diperlukan adanya empati.

Kemampuan mendengarkan menjadi alat yang efisien dalam melakukan interaksi ketika lawan bicara menunjukkan empati yang lebih besar terhadap permasalahan yang dihadapi oleh piahk yang diajak bicara (Moore et al, 1990). Empati didefinisikan sebagai kemampuan mengidentifikasi dan memahami perasaan, gagasan dan situasi individu lain (Futrell, 1998). Empai juga disebutkan sebagai dasar berkomunikasi yang lebih baik. Agar dapat mengkomunikasikan atau menyampaikan pemahamannya terhadap pesan yang disampaikan oleh lawan bicara sampai memberikan respon, pertama kali yang harus dimiliki oleh pihak yang diajak bicara adalah empati (Pilling \& Eroglu, 1994). Saat seseorang menerima pesan daripiahk lain, pihak penerima pesan yang memiliki empati yang kuat akan dapat menangkap isyarat dari lawan bicaranya, selanjutnya ketika orang tersebut mengartikan dan menilai pesan, maka yang bersangkutan akan dapat memahami isi pesan, mengiterpretasikan dan mengevaluasi pesan tersebut secara lebih gamblang dan akhirnya akan dapat memberikan respon yang tepat, cepat terhadap apa yang disampaikan oleh si pengirim pesan (Comer \& Drollinger, 1999). Dengan demikian semakin kuat empati yang dimiliki, maka kemampuan mendengarkan juga semakin meningkat. Pada sisi yang lain para ahli seperti Beveridge (1985); Morlan (1986); Sullivan (1987) serta Pilling dan Eroglu mengatakan bahwa empati adalah faktor yang

Jurnal Dinamika Sosial Budaya, Volume 19, Nomor 1, Juni 2017 
paling penting dalam komunikasi yang sukses, serta diperlukan untuk mencapai kesuksesan dalam interaksi antara pembicara dengan lawan bicarnya. (Spiro dan Weitz, 1990; Greenberg dan Amabile, 1996; serta Peterso,1999).

Dimaksud dengan kemampuan bertanya adalah kemampuan seseorang untuk mengajukan pertanyaan guna memahami pihak lawan bicara sehingga dapat membaca situasi dan kebutuhan yang mereka perlukan. Ini adalah suatu ketrampilan yang sangat penting (Shoemaker \& Johlke, 2002). Mannin \& Reese (1998) menyebutkan bahwa proses bertanya yang tepat akan membantu dalam pencapaian tujuan pelayanan.Kemampuan bertanya juga mendorong terjadinya komunikasi dua arah yang berarti antara penanya dengan yang ditanya. Studi yang dilakukan oleh William et all (1990), menemukan bahwa penanya akan lebih terbuka pada pihak lawan bicara yang mengetahui pertanyaan paling efektif

Kemampuan untuk mendapatkan informasi yang akurat, dipengaruhi oleh kecakapan seseorang dalam mengajukan pertanyaan. Dalam menyampaikan sesuatu, meeka dapat mengajukan sejumlah pertanyaan. Dengan demikian konsep ini menegaskan bahwa kemampuan mendengarkan dan bertanya dari seorang petugas memiliki pengaruh yang positif terhadap proses pelayanan yang diberikan. Bertitik tolak dari apa yang telah diuraikan di atas, maka proposisi yang kedua dapat dituliskan sebagai berikut :

$$
\text { Dengan memiliki empati dan }
$$

kemampuan komunikasi interpersonal yang baik, akan sangat menentukan tinggi rendahnya pelayanan yang diberikan. Semakin baik pelayanan yang diberikan oleh petugas diperguruan tinggi, akan semakin menarik calon mahasiswa dalam mengambil keputusan untuk melanjutkan studi

Secara piktografis hubungan tersebut dapat disajikan sebagai berikut

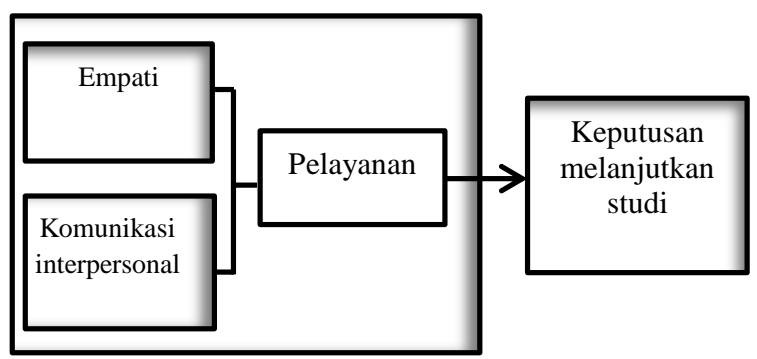

Gambar 4.2 Pelayanan di Perguruan Tinggi

\section{Bangunan Model Teori}

Berikut di bawah ini disajikan kaitan seluruh konsep yang menggambarkan tentang proposisi satu dan proposisi dua tentang keputusan melanjutkan studi

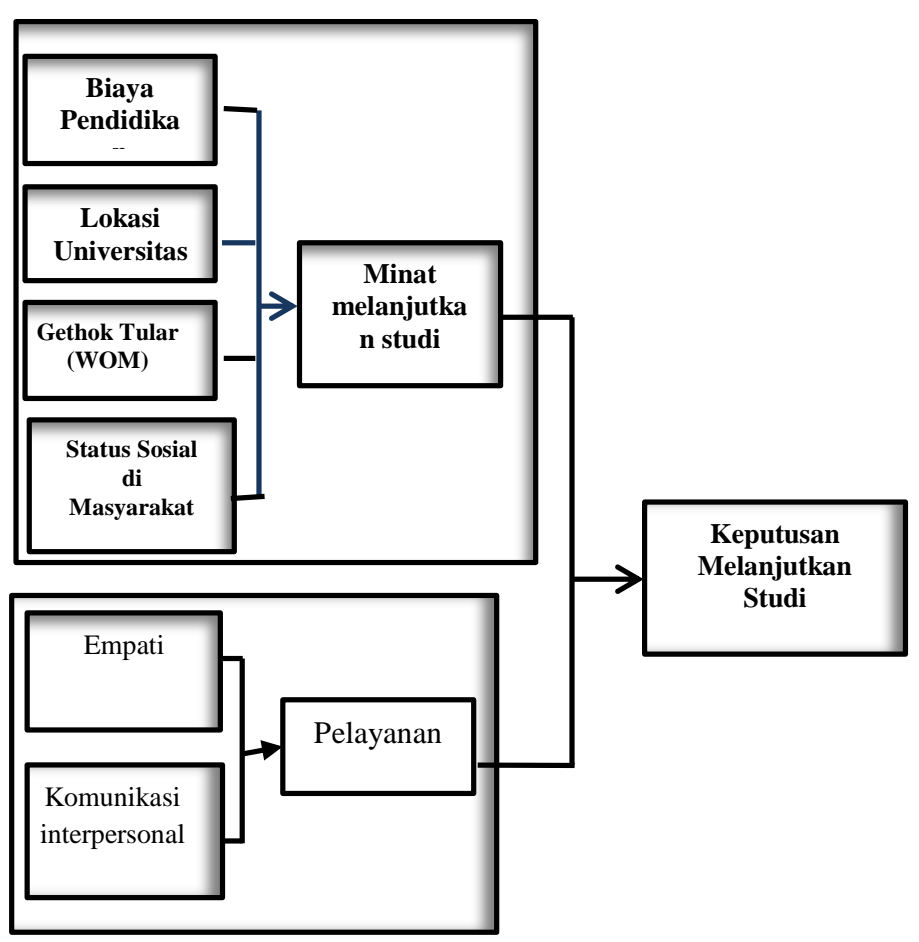

Gambar 4.3 Model Bangunan Teori Keputusan Melanjutkan Studi 


\section{Kesimpulan dan Saran}

Studi ini menghasilkan dua proposisi, proposisi pertama berkaitan dengan minat melanjutkan studi dan proposisi kedua menghasilkan pelayanan. Kedua proposisi tersebut memiliki kaitan erat dengan keputusan melanjutkan studi khususnya di Fakultas Ekonomi Universitas Semarang. Kaitan dari kedua proposisi tersebut menghasilkan bangunan teori yang berjudul teori keputusan melanjutkan studi (gambar4.3)

Untuk membuktikan kebenaran dari bangunan teori tersebut, maka perlu dilakukan adanya uji empirik lebih lanjut.

\section{Daftar Pustaka}

Arbainah, Siti, (2010)" Studi tentang Words of Mouth (WOM) Positif Pada Bisnis Ritel Pasar Modern (Kasus Empiris Pada Minimarket Alfamart dan Indomaret diKota Semarang) “ Thesis, Magister Manajemen Pascasarjana, Universitas Diponegoro, Semarang, Asnawi, S (2002).Teori Motivasi, Jakarta, Studia Press

Badudu, JS \& Zaith,S.M, (2001), Kamus Umum

Bahasa Indonesia, Jakarta : Pustaka

Sinar Harapan

Djaali, 2008, Psikologi Pendidikan, PT Bumi

Aksara

Djamara, Sayiful Bahri, (2002) Psikologi

Belajar, Rineka Cipta

Santrock, J.W. (2008), Educational Psychology, 2nd edition, Kencana Jakarta

Sardiman, 2011, Interaksi dan Motivasi Belajar Mengajar, PT Raja Grafindo Jakarta
Slavin, RE (1994) Educational Pscychology : Theory and Practice, 4th edition, Boston Allyn

Susilowati, P (2008), Memilih Jurusan di Perguruan Tinggi, www.epsikologi.com. Diakses tanggal 10/12/2008

Tjiptono, 2007, Pemasaran Jasa, Bayumedia Publishing, Malang

Winkel,W.S (1991), Psikologi Pengajaran, PT Grasindo Jakarta 